\title{
Work from home study: mental workload, gender, and calorie needs
}

\author{
Fatin Saffanah Didin ${ }^{1 *}$, Belia Perwitasari Maharani ${ }^{2}$, Intan Mardiono $^{1}$ \\ ${ }^{1}$ Department of Industrial Engineering, Institut Teknologi Sumatera, Jl. Terusan Ryacudu, Lampung Selatan 35365, Indonesia \\ 2 Department of Industrial Engineering, Universitas Mercu Buana, Jl. Raya, Meruya Selatan, Kembangan, Jakarta 11650, Indonesia
}

\begin{tabular}{l} 
ARTICLE INFORMATION \\
\hline Article history: \\
Received: November 25, 2020 \\
Revised: February 07, 2021 \\
Accepted: February 16, 2021 \\
\hline
\end{tabular}

Keywords:

RSME

Calorie needs

Gender

WFH

\section{A B S T R A C T}

Coronavirus disease (COVID-19) pandemic has changed how to work, learn, socialize, and many business sectors applied for the Work from Home (WFH) rule. This research aims to measure workers' mental and physical workload while working from home use Rating Scale Mental Effort and the physical workload was using calorie needs. The calculation for calories needs using physical condition of participant and food consumption in a day with Lifesum Application. Participants consisted of 40 males and 40 females. The result shows that the value of mental workloads on males and females with no different significance. But the average amount of female's work and mental workload effort is higher by 9.98 than men. More than $60 \%$ of male and female workers working from home belong to the category of heavy work seen from their calorie needs. According to the number of calories remaining, more than $70 \%$ of male and female workers have an excess amount of calories that is not suitable for worker health. This study suggested that employees need to improve the work system online to reach a healthy working system both mentally and physically. The relevant company can use the suggestion of this paper result in providing workload to employees during WFH.

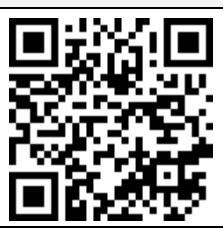

This is an open-access article under the CC-BY-NC-SA license.

*Corresponding Author

Fatin Saffanah Didin

E-mail: fatin.didin@ti.itera.ac.id

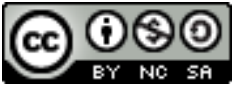

(C) 2021 Some rights reserved

\section{INTRODUCTION}

The World Health Organization (WHO) declared a global pandemic on March 11, 2020, namely coronavirus disease (COVID-19) [1]. COVID-19 was profoundly impacting the business and economy of the world. SAFER 2020 said that the COVID-19 pandemics had caused stress, fear, anxiety, and depression across the country [2], [3]. Shortly COVID-19 pandemic has changed the way we work, learn, and socialize.
Because of the changes, many business sectors applied for the Work from Home (WFH) rule for the employee to minimize the fast-spreading of COVID-19 pandemics. The Indonesian government applies for work from home to companies engaged in goods or services. This condition makes many workers work from home online.

The office work that is finished at home relies heavily on technology, such as laptop devices, smartphones, and a stable internet connection. 
Furthermore, offline jobs, such as meetings, are all done online using the online conference platform. People work in virtual and have a flexible time environment [4]. The work environment changes the worker's behavior both of male and female worker, from daily activities such as eating frequency up to worker rest time [5]. The worker (female and male) had the same workload during work from home activity. Previous research found a different eating behavior for males and females. Males significantly correlate with hunger and BMI (Body Mass Index), but females have a significant correlation in restraint and BMI [6]. Because of work from home flexibility, the workers' behavior adapted to all conditions often have meeting time in the evening through regular working hours when working offline, work anywhere and anytime at home. There are possibilities of another eating behavior while working from home situation that can impact worker's health conditions. This condition also changed the company's expectations because of a sudden increase in the employee's workload [7]. Based on Human Resource Director Asia 2020 reports, 92\% of employees feel anxiety due to the ongoing COVID-19 pandemic. A focus on workplace mental health and psychological safety is critical to surviving the survival stage [8].

This study's method uses assessment for mental workload and calorie intake for investigating problems in the workplace. Recently, previous research used Psychophysiology terms. This method looks at the relationship of healthy relations with works both on mental and physical factors. The investigation of the work system physically uses the pulse of workers and cardiovascular activities [9]. In the field of ergonomics, measurements of physiological in individuals can perform using heart rate (HR), heart rate variability (HRV) [10], and electrodermal activity (EDA). These studies are considered noninvasive, unobtrusive, objective, and provide information in real-time [11]. The measurement of physical workloads can also use the consumption-the energy of the workers. This energy consumption was influence by weight, height, age, gender, and type of physical activity [12]. While the measurement of mental workloads can be objective and subjective, the actual workload measurement can use eye-blink measures [13]. Then, the subjective mental workload that is widely used in Indonesia is the Nasa Task Load Index (NASA TLX), the Subjective Workload
Assessment Technique (SWAT) [14]. The Rating of Mental Scale Effort (RSME) is a measurement of subjective mental workload, which is onedimensional [15]-[17].

The condition of this work from home has been running for 2-3 months, where later, the government plans to continue the social distancing program while working in a healthy new era in the future. There is some different work environment while working at the office and working from home during the pandemic. The workers should adapt to the home environment, while the task load from the office is still the same as regular work in the office. However, a new habit for work such as meeting online can do over the work hours, both of colleague or client contact the workers after work hours or weekend. The workers felt increasing task load, stress, and weight gain during the pandemic possibly impacted workers' health conditions.

Previous research is concern about mental health for workers during pandemic COVID-19. There are psychological issues during pandemics such as anxiety, depression, occupational stress, PTSD, and insomnia for healthcare workers and non-healthcare workers. The result of the previous study found that both healthcare workers and nonhealthcare workers suffered in equal measures during pandemic for stress, depression except for insomnia [18]. Another evidence found that healthcare workers have experience mood and sleep disturbances during the pandemic [19].

Much research measures workers' mental and physical workload who work from home during a pandemic, especially in Indonesia. The community's income influences the habit of consuming different types of food [20], [21]. Better income and knowledge tend to make consumers demand healthier and more diversified food [22]. Demand for instant food (low-quality cereals, instant noodles, instant porridge) may decrease while fruit, vegetables, meat, fish, and dairy products are likely to increase. Because of the unpredicted condition for pandemic COVID-19, both the company and the workers need to improve the working system based on mental and physical workload.

This research was conducted using the mental workload approach using RSME and physical workload using calorie needs. It was done by virtually in the social distancing situation in Indonesia. This study is subjective to measure the mental and physical workload of workers while 
working at home. Furthermore, this measurement can use as the basis for developing a working system in the normal New Era later in Indonesia. Work systems can increase worker productivity and keep employees working healthy.

\section{RESEARCH METHODS}

\subsection{Participants}

Participants considered the workers who have done work from home for at least two months in Indonesia. Therefore, the sampling technique in getting the data was using expert sampling. The reasons for using expert sampling are to have a better way of constructing the views of individuals that are experts in a definite area [23]. Therefore, the total number of participants is 80 people, consisting of 40 males and 40 females. They have a range of ages from 20 to 52 years. Participants come from one Internet Service Company in Indonesia. Workers do work from home, covering administrative work, meetings, and customer follow-up. Working hours adjust to the average working hours performed on each worker.

\subsection{Questionnaire}

The study used mental workload questionnaires using RSME, an open questionnaire about types of food consumed by the worker, and a close questionnaire about typical food most consumed (per portion). The types of food consumption as follow in Table 1. All the food consumption by the worker is calculated using the "Lifesum Android Application". The questionnaire tested the validity and reliability of 30 people. After a valid and reliable questionnaire (Cronbach; s Alpha > 0.60), questionnaires were distributed to participants.

\subsection{Measures}

RSME is one subjective mental workload measurement that another researcher already used. The mental workload measurement used by RSME has six mental business indicators. These indicators include workloads, work difficulties, job satisfaction/performance, mental work effort, work anxiety, and work fatigue [24].

Measurement of physical workloads using calorie needs who correlate calculating the energy [25]. Calorie needs obtaining from the data height, weight, and age of workers. The workers have working activities with diverse work postures from sitting on the chair, on the floor, and asleep in front of the laptop. The calculation formula for male and female calorie needs in "Eq. (1), (2)" uses The Harris-Benedict equation [26].

Calorie needs $=66.5+13.8 x$ weight $(\mathrm{Kg})+5 x$

Height $(\mathrm{cm}) / 6.8 \times$ Age (years)

Calorie needs $=655.1+9.6 x$ weight $(\mathrm{Kg})+1.9 x$

Height $(\mathrm{cm}) / 4.7 x$ Age (years)

Table 1. Laboratory variables

\begin{tabular}{|c|c|c|}
\hline Time & $\begin{array}{c}\text { Food } \\
\text { (per portion) }\end{array}$ & $\begin{array}{c}\text { Calories } \\
\text { (kcal) }\end{array}$ \\
\hline \multirow[t]{6}{*}{ Breakfast } & Rice & 748 \\
\hline & Bread & 282 \\
\hline & Poured & 893 \\
\hline & Milk & 146 \\
\hline & Coffee & 162 \\
\hline & Tea & 86 \\
\hline \multirow[t]{5}{*}{$\begin{array}{l}\text { Morning } \\
\text { Snack }\end{array}$} & Fruits & 284 \\
\hline & Dessert & 248 \\
\hline & Snack & 560 \\
\hline & Coffee & 162 \\
\hline & $\begin{array}{l}\text { Fried Snack } \\
\text { "Gorengan" }\end{array}$ & 800 \\
\hline \multirow[t]{5}{*}{ Lunch } & Rice & 748 \\
\hline & $\begin{array}{l}\text { Additional } \\
\text { chicken/fish/meat }\end{array}$ & 990 \\
\hline & $\begin{array}{l}\text { Additional } \\
\text { vegetables }\end{array}$ & 356 \\
\hline & $\begin{array}{l}\text { rice with } \\
\text { vegetables }\end{array}$ & 1104 \\
\hline & Noodles with egg & 587 \\
\hline \multirow[t]{4}{*}{$\begin{array}{l}\text { Afternoon } \\
\text { Snack }\end{array}$} & Fruits & 284 \\
\hline & Dessert & 248 \\
\hline & Snack & 560 \\
\hline & Coffee & 162 \\
\hline \multirow[t]{5}{*}{ Dinner } & Rice & 748 \\
\hline & $\begin{array}{l}\text { Additional } \\
\text { chicken/fish/meat }\end{array}$ & 990 \\
\hline & $\begin{array}{l}\text { Additional } \\
\text { vegetables }\end{array}$ & 356 \\
\hline & $\begin{array}{l}\text { rice with } \\
\text { vegetables }\end{array}$ & 1104 \\
\hline & Noodles with egg & 587 \\
\hline
\end{tabular}

Calorie requirements classify into low (100$200 \mathrm{Kcal} / \mathrm{hr})$, medium (200-350 Kcal/hr), and heavy $(350-500 \mathrm{Kcal} / \mathrm{hr}$ ) work activity types. While in getting the calorie data intake, every worker calculates from the average eating habits of workers on breakfast, morning snack, lunch, snack afternoon, and dinner. Calorie calculations 
calculated using the Lifesum application to calculate the calorie difference can be seen in "Eq. $3 "$.

\section{Calorie Left $=$ Calorie intake- Calorie needs}

Analysis of data has done by conducting the normality test. If the data is average, then test sample T-test to see if there is a significant difference between male's and females' mental and physical workloads.

\section{RESULTS AND DISCUSSION}

\subsection{Result}

The RSME survey results for female data show the workload value of 72.25 ; Work difficulties of 73.52; Job satisfaction/performance amount of 81.5 ; mental work effort of 90.75 ; Work anxiety reached 78.32 and worked fatigue got 83.37. As for the male, the workload values reached 70.12; work difficulties of 75.25; Job satisfaction/performance amount of 76.2; Mental work effort of 80.77; Work anxiety reached 78.2, and work fatigue got 74. Fig. 1 shows a graph of RSME values for females as well as males. The chart shows that males' and females' workload while undergoing work from homework is relatively low compared to male and female mental work efforts.

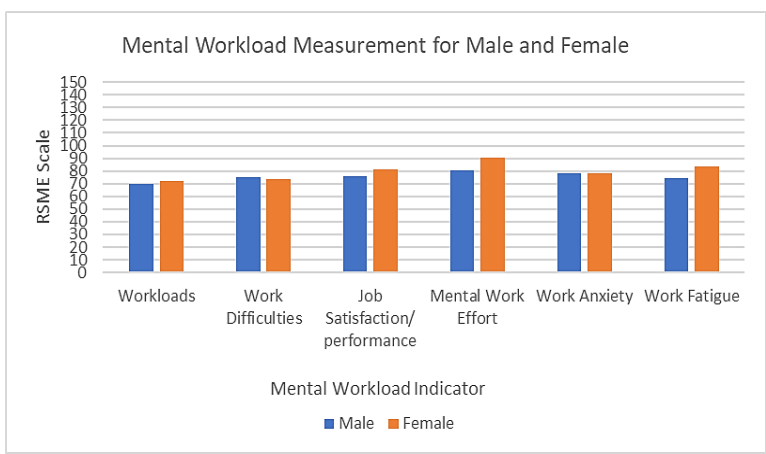

Fig. 1. Mental workload measurement for males and females

Table. 2 is the result of the physics workload measurement for both Males and Females. The results found that the majority of males experienced a reasonably high workload, $98 \%$. At the same time, females have an almost similar workload with males, which is $40 \%$ in the medium workload category, while $60 \%$ of females are in the high workload level category. Calories left for males and females are quite the same, i.e., $70 \%$ for males, while $78 \%$ for females. On the other hand, the calory left level atom for males to reach $30 \%$ while for females of $23 \%$. From the data presented in Table 2 can be inferred that with the higher workload of the worker, there is an excess of calories. The excess calories may be because the employee stays static.

Table 2. Physics workload measurement result

\begin{tabular}{cccc}
\hline & & Male & Female \\
\hline Workload & Medium & $2 \%$ & $40 \%$ \\
Categories & High & $98 \%$ & $60 \%$ \\
Calories & Shortage & $30 \%$ & $22 \%$ \\
left & Excess & $70 \%$ & $78 \%$ \\
\hline
\end{tabular}

\subsection{Discussion}

\subsubsection{Mental Workload}

The mental workload indicated that the highest value effort in males and females is cognitive workload. After being tested using statistics, the value of mental workload efforts in males and females is not significantly different. The value of a female's mental workload is higher than 9.98. Because male and female workers alike have a type of work, duty, and work duration that is quite similar, females have a disruption in the homework environment. Although the working conditions experienced at home are working online in front of the laptop, females have more obligations to homework responsibilities ranging from dismembered homes, cooking, or caring for the family [27]. Fatigue in females also has a higher value of 9.37 compared to males, and it is related to the more females' work at home. The average mental business work when males in the category of business do work from home was quite extensive, while in females, the business was done large, according to RSME.

Internal factors and external factors influence job performance. The internal factor was something that relates to a person's emotions, a person's mood condition. At the same time, the external factors were affected by the surrounding environmental conditions, such as room temperature, workplace humidity, and light conditions around the workspace. The workload described in Figure 1 indicated that the workload at home is large enough from the mental measurement results. It is influenced by the worker's boredom when it took two months while females are higher than males because females are more susceptible to stress than males. 
Otherwise, the mental workloads increased during the pandemic with the period of regular work. Workers across the world (students, medical staff, officials, service personnel, teachers, business manager, freelance, other jobs) give some perspectives that COVID-19 impact such as adverse mental health, increase levels of anxiety and quality of life rather than regular work because of the unprecedented pandemic [28], [29].

\subsubsection{Physics Workload}

In the retention of physical workloads seen from the calorie needs, $98 \%$ of male workers consider work from home as a job that is categorized as slowly seen from his calorie needs. While on workers, $60 \%$ of female employees think work from home is a job that is classified as slowly seen from her calorie needs. It is related to the age, weight, height, and daily work duration of the workers. Female workers generally have a higher working duration than males when working from home. Besides, to be seen from calorie intake from both males and females, more than $70 \%$ of workers have excess calories when working at home. Based on age classification such as young adult (18-35) and middle age (36-55) [30], there are $95 \%$ of young adult males dan $56 \%$ middleage male has calories excess.

On the other hand, $67 \%$ of young adult females have a shortage of calories. $73 \%$ of middle-aged adults have excess calories because workers increase the frequency of eating when they are doing, even though in the evening, many workers need calorie drinks or snacks to accompany their work. The food and beverages that are on-take role to increase energy and reduce the sleepiness of the workers. Excess calories are contrary to the principle of a healthy working system and have a negative impact, such as obesity, for the long-term duration [31], [32]. Obesity is potentially dangerous for young adult workers who had long duration work based on retirement age in Indonesia (56 years old) [33]. Research conducted by Dias et al. [34] can be concluded that calories can be beneficial depending on the type of activity or work done by a person. A lot of work requires a lot of movement and oxygen. Calories will be beneficial to increase a person's metabolism. But suppose the work doesn't require a lot of movement and a lot of oxygen. In that case, calories can cause several chronic diseases and functional declines related to aging, such as Parkinson's, Alzheimer's, and neuroendocrine disorders. This excess of calories also occurs because work from home activities generally requires workers to have a static posture, such as sitting for a long duration, besides the impact on excess calories. A static work posture of prolonged duration can result in fatigue.

\subsubsection{Limitations and Future Research}

This research has a physical limitation on measurement. Future mental and physical workloads can be measured objectively using a more specific type of work, considering work posture, using HR, blink rate, and calculation calories for the full-day activity for variables. The physical workloads narrowly focus on calorie needs by the workers' body condition and daily tasks during work from home. Besides, experiments can be virtually attempted in the future, using video calls to record participant activity while working to obtain more objective more real-time.

\section{CONCLUSION}

This study concludes that the value of the mental workload on males and females is not significantly different. However, judging by the average value of females' work, mental business is higher by 9.98 than males. Then seen from the physical workload, more than $60 \%$ of male workers and the female assumed that work from homework is a job in heavy work seen from the caloric needs. According to the number of calories remaining, more than $70 \%$ of male and female workers have excess calories. It was not suitable for worker health. The findings of this study not only contribute to the company but also the workers. The company can use the result to improve the work system during work from home. The workers can provide a healthy lifestyle during work from home. This study can be used as an essential improvement for support both mentally and physically worker's condition while working during pandemic from the company or the workers themselves.

\section{REFERENCES}

[1] World Health Organization, "Critical preparedness, readiness and response actions for COVID-19: interim guidance, March 22, 2020," World Health Organization, 2020. Available: https://apps.who.int/iris/handle/10665/331 511 ?locale-attribute $=$ pt $\&$. 
[2] National Safety Council, "Depression and the workplace: a progress report," National Safety Council, 2020. Available: https://www.nsc.org/getmedia/788740357036-4567-a51d-835b55f86fa8/qhmanaging-employee-anxiety.pdf.aspx.

[3] W. M. Banjar and M. K. Alaqeel, "Healthcare worker's mental health dilemma during COVID-19 pandemic: A reflection on the KSA experience," $J$. Taibah Univ. Med. Sci., vol. 15, no. 4, pp. 255-257, Aug. 2020, doi: 10.1016/j.jtumed.2020.06.006.

[4] H. D. Windarwati et al., "Stressor, coping mechanism, and motivation among health care workers in dealing with stress due to the COVID-19 pandemic in Indonesia," Asian J. Psychiatr., vol. 56, pp. 1-3, Feb. 2021, doi: 10.1016/j.ajp.2020.102470.

[5] D. Majumdar and W. Selvamurthy, "Perspectives of Ergonomics Research at Defence Institute of Physiology and Allied Sciences in India," Int. J. Ind. Ergon., vol. 25, no. 2, pp. 215-218, 2000, doi: 10.1016/S0169-8141(98)00105-X.

[6] K. Shiozawa et al., "Gender differences in eating behavior and masticatory performance: An analysis of the ThreeFactor-Eating Questionnaire and its association with body mass index in healthy subjects," J. Oral Biosci., vol. 62, no. 4, pp. 357-362, 2020, doi: 10.1016/j.job.2020.09.005.

[7] S. Bostan, M. Akbolat, A. Kaya, M. Ozata, and D. Gunes, "Assessments of Anxiety Levels and Working Conditions of Health Employees Working in COVID-19 Pandemic Hospitals," Electron. J. Gen. Med., vol. 17, no. 5, pp. 1-5, May 2020, doi: 10.29333/ejgm/8228.

[8] Human Resources Director, "Will COVID-19 drastically change the way we work?," 2020. https://www.hcamag.com/asia/specialisati on/change-management/will-covid-19drastically-change-the-way-wework/225152.

[9] M. Frankenhaeuser, "The Psychophysiology of Workload, Stress, and Health: Comparison Between the Sexes," Ann. Behav. Med., vol. 13, no. 4, pp. 197-204, Jan. 1991, doi: 10.1093/abm/13.4.197.
[10] N. Meshkati, "Heart Rate Variability and Mental Workload Assessment," in Human Mental Workload, vol. 52, P. A. Hancock and N. B. T.-A. in P. Meshkati, Eds. NorthHolland, 1988, pp. 101-115. doi: 10.1016/S0166-4115(08)62384-5

[11] J. $\mathrm{Xu}$ and E. Montague, "Psychophysiology of the passive user: Exploring the effect of technological conditions and personality traits," Int. J. Ind. Ergon., vol. 42, no. 5, pp. 505-512, 2012, doi: 10.1016/j.ergon.2012.07.007.

[12] H. Iridiastadi and Yassierli, Ergonomi suatu pengantar. Bandung: PT. Remaja Rosdakarya. 2014. Available: https://opac.perpusnas.go.id/DetailOpac.a spx?id=923779

[13] A. Magliacano, S. Fiorenza, A. Estraneo, and L. Trojano, "Eye blink rate increases as a function of cognitive load during an auditory oddball paradigm," Neurosci. Lett., vol. 736, p. 135293, 2020, doi: 10.1016/j.neulet.2020.135293.

[14] G. B. Reid and T. E. Nygren, "The Subjective Workload Assessment Technique: A Scaling Procedure for Measuring Mental Workload," in Human Mental Workload, North-Holland Amsterdam, 1988, pp. 185-218. doi: 10.1016/S0166-4115(08)62387-0

[15] A. Widyanti, A. Johnson, and D. de Waard, "Adaptation of the Rating Scale Mental Effort (RSME) for use in Indonesia," Int. J. Ind. Ergon., vol. 43, no. 1, pp. 70-76, Jan. 2013, doi: 10.1016/j.ergon.2012.11.003.

[16] A. Widyanti, A. Johnson, and D. de Waard, "Pengukuran beban kerja mental dalam searching task dengan metode rating scale mental effort (RSME)," J@ Ti Undip, no. 1, pp. 1-6, 2010. Available: https://ejournal.undip.ac.id/index.php/jgti/ article/view/2027.

[17] S. G. Hart, "Nasa-Task Load Index (NASA-TLX); 20 Years Later," Proc. Hum. Factors Ergon. Soc. Annu. Meet., vol. 50, no. 9, pp. 904-908, Oct. 2006, doi: 10.1177/154193120605000909.

[18] M. Sheraton, N. Deo, T. Dutt, S. Surani, D. Hall-Flavin, and R. Kashyap, "Psychological effects of the COVID 19 pandemic on healthcare workers globally: A systematic review," Psychiatry Res., vol. 
292, p. $113360, \quad 2020, \quad$ doi: 10.1016/j.psychres.2020.113360.

[19] S. Pappa, V. Ntella, T. Giannakas, V. G. Giannakoulis, E. Papoutsi, and P. Katsaounou, "Prevalence of depression, anxiety, and insomnia among healthcare workers during the COVID-19 pandemic: A systematic review and meta-analysis," Brain. Behav. Immun., vol. 88, pp. 901907, 2020, doi: 10.1016/j.bbi.2020.05.026.

[20] H. Toiba, "Food consumption and shopping pattern change in Indonesian urban consumers: A cluster approach," 2016.

Available:

https://www.researchgate.net/publication/ 305281398.

[21] S. Min, X. Wang, and X. Yu, "Does dietary knowledge affect household food waste in the developing economy of China?," Food Policy, vol. 98, p. 101896, 2021, doi: 10.1016/j.foodpol.2020.101896.

[22] B. Arifin, N. A. Achsani, D. Martianto, L. K. Sari, and A. H. Firdaus, "Modeling the future of Indonesian food consumption," 2018. Available: https://docs.wfp.org/api/documents/WFP0000073760/download/.

[23] I. Etikan, "Sampling and Sampling Methods," Biometrics Biostat. Int. J., vol. 5, no. 6, pp. 215-217, May 2017, doi: 10.15406/bbij.2017.05.00149.

[24] B. Fista et al., "Review of Cognitive Ergonomic Measurement Tools," IOP Conf. Ser. Mater. Sci. Eng., vol. 598, no. 1, pp. 1-9, Sep. 2019, doi: 10.1088/1757899X/598/1/012131.

[25] B. M. Appelhans et al., "Beverages contribute extra calories to meals and daily energy intake in overweight and obese women," Physiol. Behav., vol. 122, pp. 129-133, 2013, doi: 10.1016/j.physbeh.2013.09.004.

[26] A. M. Roza and H. M. Shizgal, "The Harris Benedict equation reevaluated: resting energy requirements and the body cell mass," Am. J. Clin. Nutr., vol. 40, no. 1, pp. 168-182, Jul. 1984, doi: 10.1093/ajen/40.1.168.
[27] J. H. Gallaway and A. Bernasek, "Gender and Informal Sector Employment in Indonesia," J. Econ. Issues, vol. 36, no. 2, pp. 313-321, Jun. 2002, doi: 10.1080/00213624.2002.11506473.

[28] J. Billings, B. C. F. Ching, V. Gkofa, T. Greene, and M. Bloomfield, "Healthcare Workers' Experiences of Working on the Frontline and Views About Support During COVID-19 and Previous Pandemics: A Systematic Review and Qualitative Meta-Synthesis," Res. Sq., pp. 1-30, 2021, doi: 10.21203/rs.3.rs322448/v1.

[29] S. Yuan et al., "Comparison of the Indicators of Psychological Stress in the Population of Hubei Province and NonEndemic Provinces in China During Two Weeks During the Coronavirus Disease 2019 (COVID-19) Outbreak in February 2020," Med. Sci. Monit., vol. 26, pp. 1-10, Apr. 2020, doi: 10.12659/MSM.923767.

[30] N. M. Petry, "A Comparison of Young, Middle-Aged, and Older Adult TreatmentSeeking Pathological Gamblers," Gerontologist, vol. 42, no. 1, pp. 92-99, Feb. 2002, doi: 10.1093/geront/42.1.92.

[31] D. Benton and H. A. Young, "Reducing Calorie Intake May Not Help You Lose Body Weight," Perspect. Psychol. Sci., vol. 12, no. 5, pp. 703-714, Sep. 2017, doi: 10.1177/1745691617690878.

[32] S. Camacho and A. Ruppel, "Is the calorie concept a real solution to the obesity epidemic?," Glob. Health Action, vol. 10, no. 1, p. 1289650, Jan. 2017, doi: 10.1080/16549716.2017.1289650.

[33] Peraturan Pemerintah Republik Indonesia, Peraturan Pemerintah Republik Indonesia Nomor 45 Tahun 2015 tentang Penyelenggaraan Program Jaminan Pensiun. 2015. https://peraturan.bpk.go.id/Home/Details/ 5613/pp-no-45-tahun-2015

[34] I. R. Dias et al., "Does calorie restriction improve cognition?," IBRO Reports, vol. 9, pp. 37-45, 2020, doi: 10.1016/j.ibror.2020.05.001. 